\title{
The rediscovery of Perret's toad, Amietophrynus perreti (Schiøtz, 1963) after more than 40 years, with comments on the species' phylogenetic placement and conservation status
}

\author{
Abiodun B. Onadeko ${ }^{1}$, Mark-Oliver Rödel ${ }^{2}$, H. Christoph Liedtke ${ }^{3}$ and Michael F. Barej ${ }^{3}$ \\ 1 Department of Zoology, Faculty of Sciences, University of Lagos, Akoka, Yaba, Lagos, Nigeria \\ 2 Museum für Naturkunde, Leibniz Institute for Evolution and Biodiversity Science, Invalidenstrasse 43, 10115 Berlin, Germany \\ 3 Department of Environmental Science (Biogeography), University of Basel, Klingelbergstrasse 27, 4056 Basel, Switzerland
}

http://zoobank.org/1E6DF705-A761-4F24-8AE8-D16B702CC852

Corresponding author: Mark-Oliver Rödel (mo.roedel@mfn-berlin.de)

Received 9 July 2014

Accepted 19 Aug 2014

Published 1 October 2014

Academic editor:

Peter Bartsch

\section{Key Words}

\section{Amphibia}

Anura

Bufonidae

conservation

ecology

inselberg

morphology

Nigeria

phylogeny

systematics

West Africa

\begin{abstract}
Perret's toad, Amietophrynus perreti, has not been seen since 1970 and thus believed to be lost. We searched for the species 50 years after its original description and successfully recorded its continued presence at the type locality, where it seems to maintain a viable population. We failed however, to record the species at suitable sites elsewhere and $A$. perreti could thus indeed be a micro-endemic species, specialized and restricted to the granite inselbergs of the Idanre Hills, Nigeria. We recorded and discuss potential threats and suggest keeping the toad's current conservation status as 'Vulnerable'. We investigated the systematic status of Perret's toad using a mitochondrial fragment of the $16 \mathrm{~S}$ rRNA gene and could confirm that it is a member of the genus Amietophrynus despite its aberrant larval biology, different to the rest of the genus. In spite of this biological difference, $A$. perreti is not a phylogenetically isolated lineage, but is nested within a clade of western African Amietophrynus species, such as A. maculatus, A. regularis, A. latifrons and $A$. togoensis and is sister to the widespread and savannah dwelling A. maculatus.
\end{abstract}

\section{Introduction}

In 1963 Arne Schiøtz described a new toad from inselbergs, isolated old granite outcrops, in the Idanre Hills "near Idanre Resthouse, Ondo Province", southwestern Nigeria (Schiøtz 1963). This new species, Bufo perreti, dedicated to the Swiss herpetologist Jean-Luc Perret, is morphologically similar to the common African toad species Amietophrynus maculatus (Hallowell,
1854) and A. regularis (Reuss, 1833). However, among various morphological details the new species differed by a fundamentally aberrant breeding biology. Whereas all other known Amietophrynus species deposit strings with numerous small eggs in water (Liedtke et al. 2014), from which exotrophic and aquatic tadpoles with very similar morphologies are hatching (compare Channing et al. 2012), A. perreti has semi-terrestrial egg deposition (Tandy and Keith 1972) and very slender shaped, semi- 


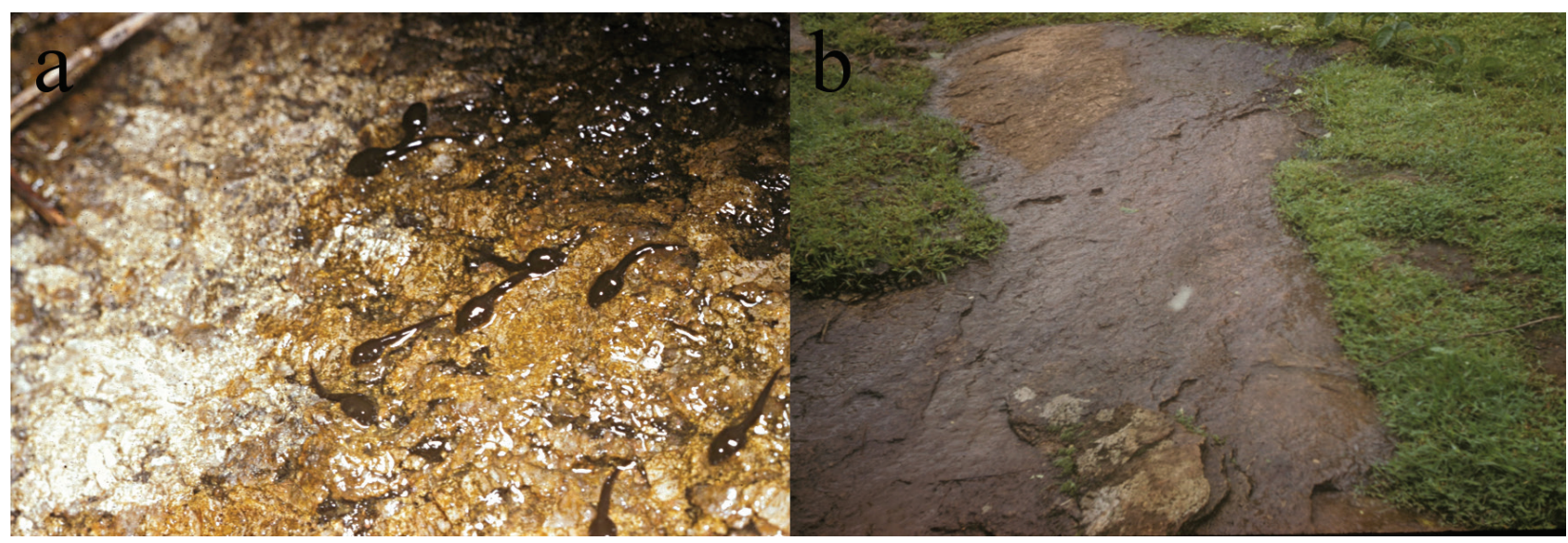

Figure 1. Habitat (right) of Amietophrynus perreti tadpoles (left) at the type locality, the Idanre Hills in Nigeria (photos: courtesy of A. Schiøtz).

terrestrial tadpoles, developing in shallow water-films on wet, sometimes vertical rocks (Schiøtz 1963; Fig. 1).

Since its description the species has rarely been mentioned in the literature. Based on osteological characters (Martin 1972) and acoustic criteria (Tandy and Keith 1972) it was placed in a monotypic group within the genus Bufo. Mills Tandy studied the three toads $A$. perreti, $A$. maculatus and A. regularis in 1964 and 1965, occurring in sympatry at the $A$. perreti type locality, and observed that they differ in size, advertisement call parameters, reproductive season and biology, as well as in microhabitat selection (Tandy and Keith 1972). Based on karyology ( $2 \mathrm{n}=$ 20; Bogart 1968), but without genetic data, Frost et al. (2006) transferred B. perreti into their new genus Amietophrynus, and Channing et al. (2012) redescribed the tadpoles. Schiøtz and Tandy (2004) and Stuart et al. (2008) give the conservation status of the species as 'Vulnerable'.

However, only Mills Tandy seems to have collected new data from the field (Tandy and Keith 1972) and until now, the species is still only known from its type locality. On the webpage of the Amphibian Survival Alliance (ASA 2014) Amietophrynus perreti is listed as being lost, the last observation dating to 1970 . We do not know from which data the later date stems. In 2013, 50 years after its original description, we decided to search for the species. Our aims were fourfold: i) document if the species still exists at the type locality, ii) collect data on the population status, iii) search in neighbouring areas for further populations, and iv) investigate the systematic position of this species.

\section{Material and methods}

All field work was carried out by two persons (ABO and a field assistant) in the Idanre Hills, Ondo Province, south-western Nigeria (approximately $7^{\circ} 06^{\prime} \mathrm{N}, 5^{\circ} 06^{\prime} \mathrm{E}$; see Appendix). The region was visited three times; the first visit from 10-12 October 2013 was only used to get familiar with the topography and to select a suitable field assistant. The second visit took place at the beginning of the dry season (26-28 October 2013). During three days and two nights we applied visual and acoustic encounter surveys (compare Rödel and Ernst 2004) at three sites (see below). Day surveys were conducted at all sites while night surveys were conducted at sites $\mathrm{A}$ and $\mathrm{C}$ only. The third visit comprised one day and one night survey at sites A and B, respectively, and took place from 13-14 March 2014, the ending of the dry season (Table 1).

Site A ( $\left.7^{\circ} 06^{\prime} 37.3^{\prime \prime} \mathrm{N}, 5^{\circ} 06^{\prime} 24.1^{\prime \prime} \mathrm{E}\right)$ comprised approximately 2 ha situated between two huge rocks, only about $50 \mathrm{~m}$ from the town of Idanre (Fig. 2a, c). Water flowed in two valleys between these rocks. The vegetation consisted mainly of shrubs and small trees. Site B $\left(7^{\circ} 06^{\prime} 14.2^{\prime \prime} \mathrm{N}\right.$, $\left.5^{\circ} 04^{\prime} 41.3^{\prime \prime E}\right)$, covering about 1.5 ha, was approximately $250 \mathrm{~m}$ height on the rocks. This area was relatively flat with patches of vegetation, shrubs and trees, growing on the rocks. Water was flowing down from higher locations, forming rock-pools in some depressions (Fig. 2b). Site $\mathrm{C}\left(7^{\circ} 06^{\prime} 32.9^{\prime \prime} \mathrm{N}, 5^{\circ} 04^{\prime} 28.0^{\prime \prime} \mathrm{E}\right)$ was part of a cocoa farm adjacent to a large inselberg, including a creek flowing through the farm (Fig. 2e). The creek had a rocky bottom and was $6-11 \mathrm{~cm}$ deep. Along the water course, there were few grasses and shrubs.

In addition, we surveyed two further sites with similar habitats (rocky inselbergs). Ikere was about $28 \mathrm{~km}$ from Idanre. Two areas were surveyed here on 3-4 November 2013 and 16 March 2014. Site 1 comprised giant rocks and was surveyed for 6 and 4 hours per day and night, respectively ( 3 day and 2 night surveys, each 2 hours length). With the same sampling effort we investigated site 2, a cocoa plantation near rocks. The second area was situated about $6 \mathrm{~km}$ from Akure and was searched on 6 November 2013 for 3.5 hours during the day and night, respectively. A map of all surveyed sites is provided in Figure 3.

All amphibians encountered were recorded. A few vouchers were collected to ascertain species determination. They were euthanized in a chlorobutanol solution and preserved in $75 \%$ ethanol. Vouchers are deposited at the zoological collection of A.B. Onadeko at the University of Lagos (no accession numbers) and at the Museum für Naturkunde Berlin (see Appendix for ZMB and GenBank 

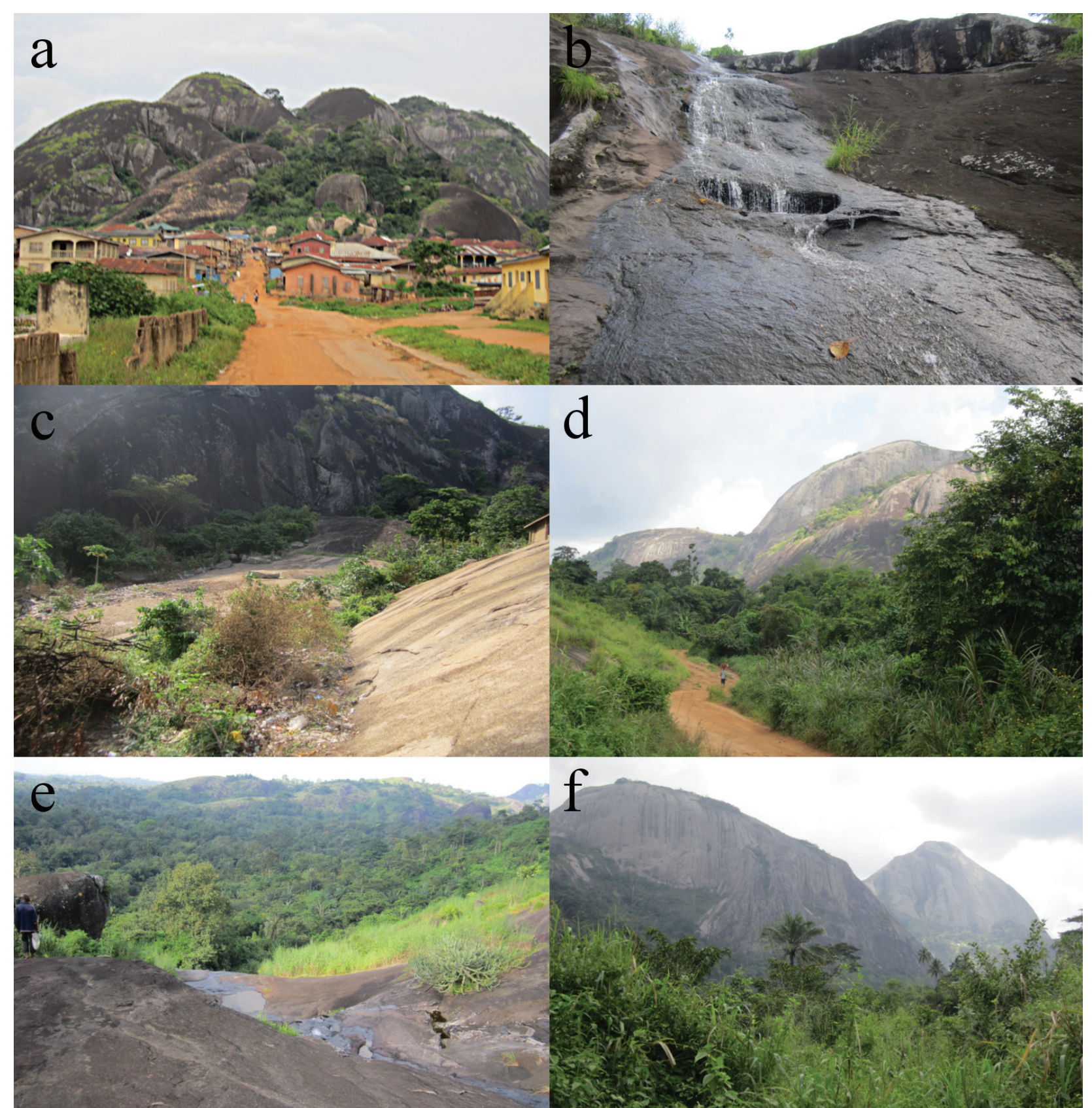

Figure 2. The Idanre Hills inselbergs in south-western Nigeria (a-f), the type locality and only known habitat of Amietophrynus perreti. Survey site A was only about $50 \mathrm{~m}$ from the last house in a; b: figures a overflown part of rock at site B; c: some A. perreti were observed close to the waste dumping site (left at the rock base), probably feeding on flies or other insects; d: a road leading to Site $\mathrm{C}$, the cocoa farm being further in the background adjacent to the large rock; e: part of site $\mathrm{C}$.

Table 1. Time period and time span spent searching for Amietophrynus perreti per site in the Idanre Hills. In parenthesis total search time per site is given in person-hours.

\begin{tabular}{c|c|c|c|c}
\hline Date & \multicolumn{2}{|c|}{$\mathbf{2 6 - 2 8}$ October 2013 } & 13 March 2014 & 14 March 2014 \\
\hline Site / time & Day & night & day & night \\
\hline A (17p-h) & $14: 00 \cdot 16: 00$ & $21: 00 \cdot 23: 00$ & $15: 00 \cdot 17: 30$ & $21: 00 \cdot 23: 00$ \\
\hline B (16p-h) & $08: 00 \cdot 10: 00$ & - & $08: 00 \cdot 11: 00$ & $18: 00 \cdot 21: 00$ \\
\hline C (6p-h) & $11: 00 \cdot 13: 00$ & $19: 00 \cdot 20: 00$ & - & - \\
\hline
\end{tabular}

accession numbers). Muscle samples of some toads were investigated to test for their systematic placement. Unfortunately only two samples could be genotyped, probably due to impure ethanol used for tissue storage. For the molecular procedures applied compare Rödel et al. (2012). Sequences, ca. 575 base pairs of the mitochondrial 16S gene, 


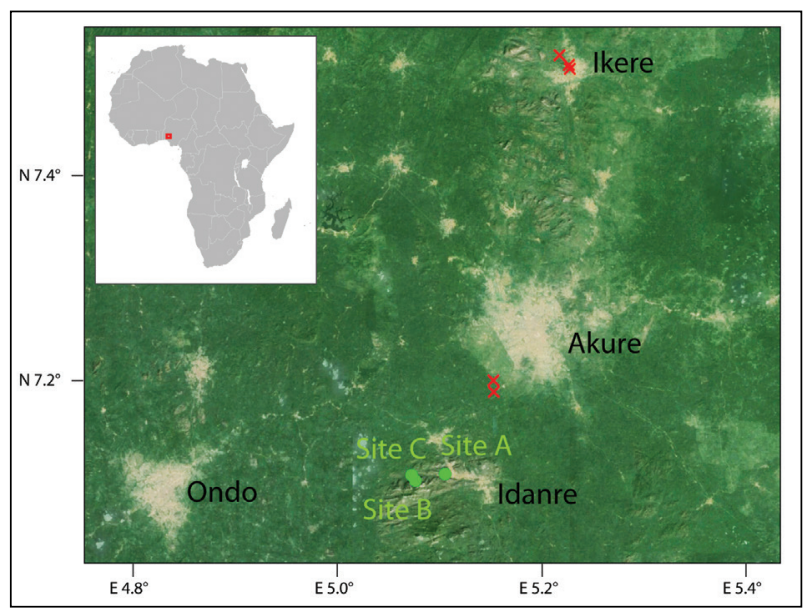

Figure 3. Sites around Idanre Hills surveyed for Amietophrynus perreti; green circles: toads recorded, red crosses: toads not found.

were compared to GenBank data as well as sequences for additional Amietophrynus species of interest (see results). Sequences were aligned using MAFFT v7.017 (Katoh and Standley 2013) and a Bayesian phylogenetic inference was carried out using MrBayes version 3.2.2 (Ronquist et al. 2012). Four independent runs were executed to assess convergence, each for 3 million generations, sampling every 1000 generations. Four chains per run were allowed to sample across the entire general time reversible substitution model space and the first $10 \%$ of each run were discarded as burn-in before generating a $50 \%$ majority-rule consensus tree from the posterior tree samples. Uncorrected $16 \mathrm{~S}$ p-distances of $A$. perreti and included Amietophrynus spp. were calculated using PAUP* 4b10 (Swofford 2003).

\section{Results}

Occurrence, abundance and threats. We rediscovered Amietophrynus perreti and observed them in sympatry with A. regularis, Phrynobatrachus spp. and Arthroleptis spp. at the study sites of the Idanre Hills inselbergs. We did not observe any A. maculatus, known to occur here as well (Tandy and Keith 1972). Occasionally we spotted $A$. regularis in close vicinity to $A$. perreti, but then usually at the rock bases. A. regularis were particularly dominant around the town of Idanre, where $A$. perreti was lacking. Puddle frogs, Phrynobatrachus, were observed on the rocks, in vegetation around water-filled rock-pools. Arthroleptis were abundant in the cocoa farm and in tertiary vegetation but absent from the rocks. In total we observed 111 A. regularis, 49 Phrynobatrachus spp. and 98 Arthroleptis spp. during 39 person-hours of searching.

Amietophrynus perreti (Fig. 4) were observed during day and night, mainly on higher parts of the rocks. They were encountered on the hard rock surfaces and among low herbal vegetation on sandy soil between the rocks. During October 2013 we observed a total of $31 \mathrm{~A}$. perreti, 16 during the day (12 person-hours search time, Table 1) and 15 during the night (6 p-h). In March 2014 we

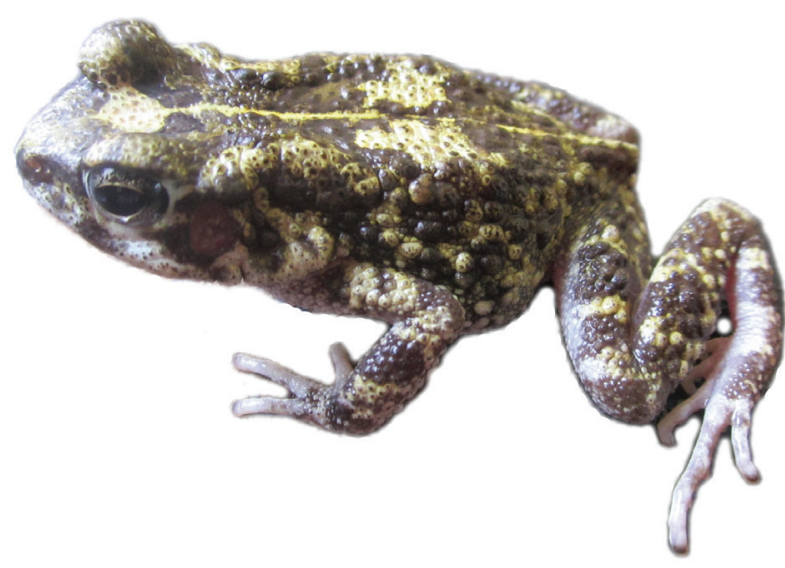

Figure 4. A specimen of the rediscovered Amietophrynus perreti from the type locality, the Idanre Hills, south-western Nigeria.

recorded a total of $12 \mathrm{~A}$. perreti, 5 during day $(11 \mathrm{p}-\mathrm{h})$ and 7 (10 p-h) during night time (Table 2). Compared to the other anuran taxa, A. perreti had the lowest abundances.

We observed two potential threats to the survival of the toads. Most importantly some areas around the sites are being cleared for cocoa plantations, the major cash crop in the region. At higher places on the rocks some crops such as pepper, corn and banana are planted. Another cash making venture is the intense cutting of trees that grow among the rocks.

We could not observe $A$. perreti in two other localities, namely Akure, $6 \mathrm{~km}$ and Ikere, about $28 \mathrm{~km}$ from Idanre. Both had similar habitats and topography compared to the A. perreti type locality.

Morphology. We examined three male and four female $A$. perreti vouchers (see Appendix). The males' snoutvent-lengths (SVL: 39.4-40.2 $\mathrm{mm}$ ) were within the range Schiøtz (1963) and Tandy and Keith (1972) provided for their specimens. None of the presumed male toads exhibited nuptial pads (dry season and hence no reproductive season). The females (55.3-64.4 mm SVL) slightly exceeded the sizes of the known females (Schiøtz 1963, Tandy and Keith 1972). Small differences to the original description concern the size of the metatarsal tubercles, being quite big and clearly distinct (larger in females than in males), and the presence of small, very flat and indistinct warts on the top of the head (no warts according to original description). All toads had comparatively flat heads, slightly pointed in lateral view (rounded in A. regularis and $A$. maculatus), almost no webbing between toes (distinct webbing between toes in $A$. regularis and A. maculatus), no tarsal fold (present in A. regularis and $A$. maculatus), and a white throat in males (dark in A. regularis and A. maculatus). In the preserved vouchers (some of them very flattened after transportation) the parotid glands ranged from less distinct to slightly more pronounced than in A. maculatus, but they were never as huge and smooth as in A. regularis. All our vouchers had more or less the same dorsal pattern as the holotype (compare Fig. 4). In life they have the olive (to yellowish) tinge Schiøtz (1963) mentioned in his description. All 
Table 2. Number of Amietophrynus perreti observed at the three study sites (compare Table 1 and site descriptions in material and methods section).

\begin{tabular}{c|c|c|c|c|c}
\hline Date & \multicolumn{2}{|c|}{ 26-28 October 2013 } & 13 March 2014 & 14 March 2014 & Total \\
\hline Site / time & day & night & day & night & 28 \\
\hline A (17p-h) & 9 & 11 & 3 & 5 & 9 \\
\hline B (16p-h) & 5 & 0 & 2 & 2 & 6 \\
\hline C (6p-h) & 2 & 4 & 0 & 0 & \\
\hline
\end{tabular}

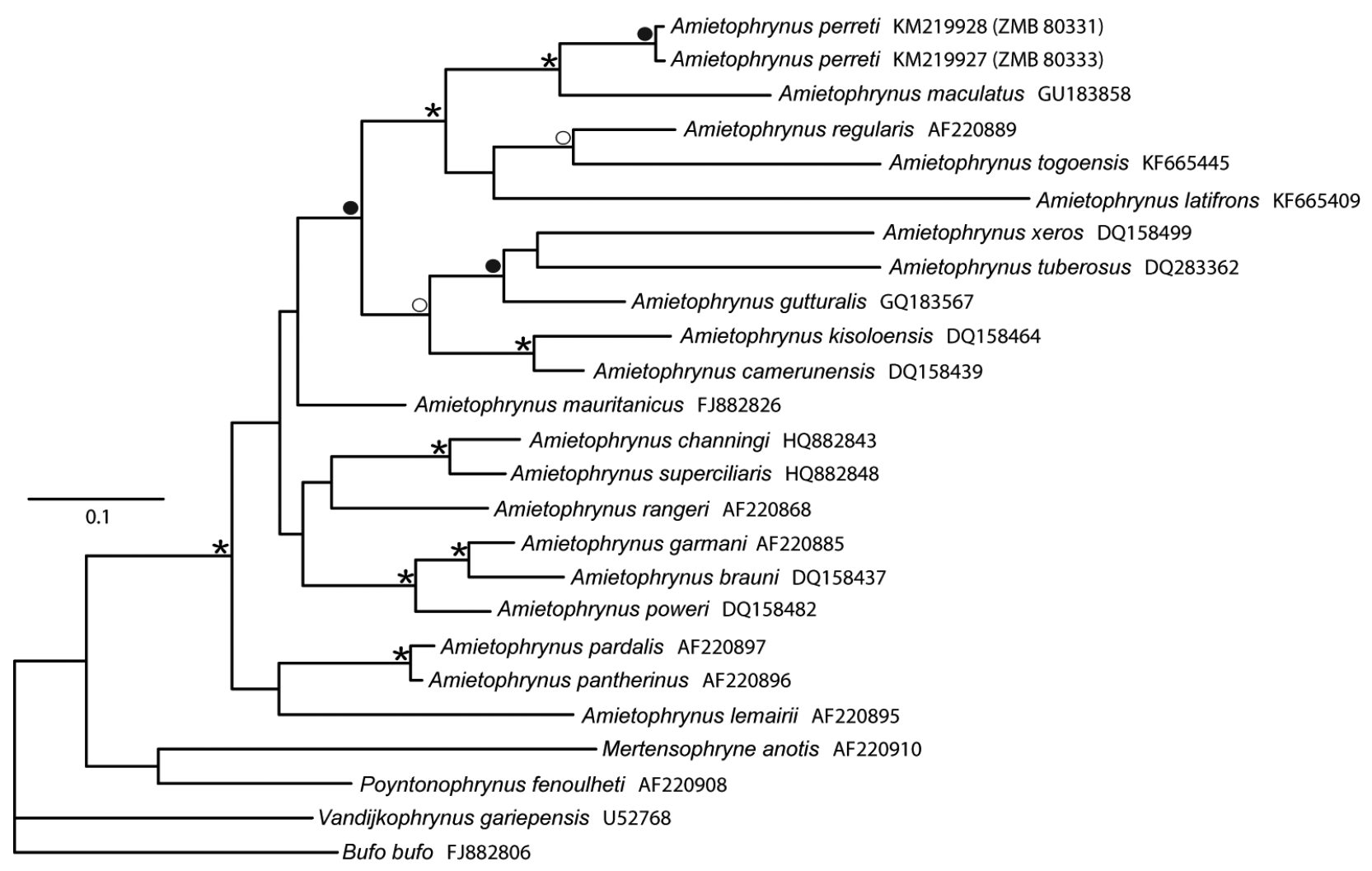

Figure 5. Systematic placement (Bayesian phylogenetic inference based on a mitochondrial fragment of the 16S rRNA gene) of Amietophrynus perreti within the genus Amietophrynus. Bayesian PP values are as follows: asterisks ('*') point to maximum support (1.00), full circles (' $\bullet$ ') point to PP 0.95-0.99; empty circle (' $\circ$ ') point to PP 0.90-0.94; PP values below 0.90 not shown.

preserved animals had a much clearer and more contrasting pattern than $A$. regularis and $A$. maculatus.

Generic assignment. Tandy and Keith (1972) placed $A$. perreti in its own, monotypic group, although having the same number of chromosomes as the A. regularis-maculatus-latifrons complex $(2 \mathrm{n}=20$, Bogart 1968). A crossing of a female $A$. maculatus with a male $A$. perreti produced some embryos to the larval stage, however none of them reached metamorphosis (Blair 1972) [such crossing worked to gastrula or even larval stage even with American species nowadays placed in different genera, namely Anaxyrus boreas, see Blair 1972].

Our Bayesian phylogenetic inference based on $16 \mathrm{~S}$ sequence data placed $A$. perreti as sister to A. maculatus (Fig. 5), with a pair-wise base difference of $7.3 \%$ (GenBank: GU183858). Pair-wise differences with other African Amietophrynus were: $7.86 \%$ in A. mauritanicus (GB: FJ882826), 9.25\% in A. channingi (HQ882843), $9.29 \%$ in $A$. regularis (GB: AF220889), $9.60 \%$ in $A$. gutturalis (GB: GQ183567), 9.64\% in A. camerunensis (GB: DQ158439), 9.64\% in A. poweri (GB: DQ158482), $9.66 \%$ in $A$. superciliaris (GB: HQ882848), $9.82 \%$ in $A$. kisoloensis (GB: DQ158464), 9.87\% in A rangeri (GB: AF220868), $10.26 \%$ in $A$. pardalis (GB: AF220897), $10.43 \%$ in $A$. pantherinus (GB: AF220896), $10.47 \%$ in A. garmani (GB: AF220885), $11.19 \%$ in A. brauni (GB: DQ158437), $11.23 \%$ in A. lemairii (GB: AF220895), $11.66 \%$ in $A$. latifrons (GB: KF665409), $12.15 \%$ in A. xeros (GB: DQ158499), $12.29 \%$ in A. tuberosus (GB: DQ283362), and $12.42 \%$ in A. togoensis (GB: KF665445). There were no base pair differences between the two sequenced $A$. perreti specimens.

\section{Discussion}

We succeeded in rediscovering Amietophrynus perreti at its type locality, 50 years after its original 
description, and 43 years after the last observation, if the date of 1970 is correct (ASA 2014). A welcome byproduct of our investigations was that we could confirm the morphological description of the species by Schiøtz (1963), and more importantly, confirm that it is indeed a member of the genus Amietophrynus. It was however, surprising, and in contrast to the osteological results of Martin (1972) and the biological and acoustical analyses of Tandy and Keith (1972), that A. perreti has no isolated phylogenetic position within the genus, but seems to be most closely related to the savannah dwelling A. maculatus (see Rödel 2000 for details of the biology of this species). The $16 \mathrm{~S}$ sequence data did not sufficiently resolve a number of nodes in the phylogeny, however, the Amietophrynus crown group was well supported, as was the $A$. perreti-maculatusregularis-latifrons-togoensis clade.

The long time gap since the previous observations and the rediscovery of the toad was not due to particular rarity of the species but can be explained by the fact that nobody else searched for the species. We found the toad being locally quite abundant, although our search time at the beginning and towards the end of the dry season certainly was suboptimal. According to Tandy and Keith (1972) A perreti reproduces during the core rainy season.

Due to their age and peculiar edaphic and climatic conditions, inselbergs are very special habitats with often unique plant and animal communities (Porembski and Barthlott 2000). Unfortunately, so far they have attracted almost exclusively the attention of geologists and botanists. We only know a few studies either focusing entirely (e.g. McLachlan and Cantrell 1980, McLachlan 1981, Osborne and McLachlan 1985, Köhler and Böhme 1996, Schorr 2003) or partly on amphibians on inselbergs (Rödel 1998). As far as we know, A. perreti is the only African anuran species depending exclusively on this habitat type. Schiøtz and Tandy (2004) speculate that $A$. perreti may occur in other areas of western Nigeria, offering similar habitats, but we did not record the species in two similar areas in closer vicinity of the type locality, nor was the species recorded by Onadeko and Rödel (2009) from other sites in south-western Nigeria. It thus seems possible that $A$. perreti is indeed an endemic species of the Idanre Hills.

During the current survey we observed no tadpoles of A. perreti. However, the tadpoles require a constant water film on the rocky surfaces where they graze on algae (Fig. 1), most likely in a situation like figured in Figure $2 b$. During the dry season, although occasional rains occur, such habitats do not exist. A reason for the absence of $A$. perreti on other inselbergs might be that the existence of this species, with its very special reproductive biology, requires an environment with high humidity persisting for prolonged periods and some water storing vegetation. Only then it seems possible that a constant water film on the rocks is maintained and provides the tadpoles of $A$. perreti with enough time to finish metamorphosis. The tadpoles seem to actively avoid deeper water and in- stantly, when forced into water, climb out again (Schiøtz 1963), showing a behavior comparable to some Petropedetes tadpoles (Barej et al. 2010). It thus seems that they will not make use of deeper rock-pools (Fig. 2e) and ultimately depend on the wet rock surfaces (Fig. 1).

We know from other inselbergs in the forest zone of Ivory Coast, that these provide a much hotter and dryer environment compared to the surroundings and thus are home to true savannah species, even within a rainforest matrix (Schorr 2003). The fact that true forest in south-western Nigeria disappeared almost completely (see Onadeko and Rödel 2009), may explain that $A$. perreti simply cannot survive on other nearby inselbergs because the overall climate is too hot and dry. Already Schiøtz (1963) had failed to record the species in nearby inselbergs, surrounded by savannah vegetation. It is also possible that the mere dimensions of the inselberg landscape near Idanre are simply unequaled elsewhere.

According to the original description (Schiøtz 1963) A. perreti is abundant within its habitat. Arne Schiøtz collected 16 adults in July and August, 10 semi-adults and juveniles in January, July and August and 74 tadpoles in July and August 1961. On our surveys we likewise encountered the species frequently, although probably less frequent than Schiøtz (1963). We guess that the toads are not only reproducing during the rainy season (Tandy and Keith 1972), but that this is also the peek activity period and that the Idanre Hills population is still in good shape. The population thus seems viable, but we do not entirely agree with the judgment of Schiøtz and Tandy (2004) that the species does not face "any serious threats at present" because the "rocky habitat is largely inaccessible and useless to humans". Schiøtz (1963) reported that he found all adults at night on bare rocks. He heard males calling in July 1961 during daytime, the voices coming from "very small patches of grass and low vegetation on the rocks, never from the wooded area" (Schiøtz 1963). Tandy and Keith (1972) report similar observations. It thus seems that the toads, at least during the rainy season, do not need forested areas. However, we believe that the current clearing of larger trees from the area, and the use of smaller patches to grow various crops on the rocks may result in a changing micro-climate and altered hydrology, both potentially affecting the toad's survival, especially during the dry season when humid areas are rarer. In addition, the close proximity to a human settlement and to cash crop plantations may expose the toads to agrochemicals and other potentially harmful pollutants.

As the species could not yet be recorded from any other site, the only known population deserves particular attention. Schiøtz and Tandy (2004) already wrote that the species "is intrinsically at risk because of its restricted range". We thus urge, and agree with Schiøtz and Tandy (2004), for setting up a continuous monitoring program of this population and suggest aiming for a protection status for the Idanre Hills in order to assure the long-term survival of Perret's toad. 


\section{Acknowledgements}

We thank the Chiefs and town elders of Idanre, as well as our field assistant Mr. Layi, allowing access to their community land. ABO also wishes to thank his wife, Mrs. F. Onadeko, who partly funded the survey costs. A. Schiøtz permitted the use of the photos in Fig. 1.

\section{References}

ASA (2014) Search for lost frogs. http://www.amphibians.org/lostfrogs. [Last accessed on 1 June 2014]

Barej MF, Rödel M-O, Gonwouo LN, Pauwels OSG, Böhme W, Schmitz A (2010) Review of the genus Petropedetes Reichenow, 1874 in Central Africa with the description of three new species (Amphibia: Anura: Petropedetidae). Zootaxa 2340: 1-49.

Blair WF (1972) Evidence from hybridization. In: Blair WF (Ed.) Evolution in the genus Bufo. University of Texas Press, Austin \& London, 196-232.

Bogart JP (1968) Chromosome number difference in the amphibian genus Bufo: the Bufo regularis species group. Evolution 22: 42-45. doi: $10.2307 / 2406648$

Channing A, Rödel M-O, Channing J (2012) Tadpoles of Africa - The biology and identification of all known tadpoles in sub-Saharan Africa. Frankfurt Contributions to Natural History, Vol. 55, Edition Chimaira, Frankfurt/M.

Frost DR, Grant T, Faivovich J, Bain RH, Haas A, Haddad CFB, de Sá RO, Channing A, Wilkinson M, Donnellan SC, Raxworthy JC, Campbell JA, Blotto BL, Moler P, Drewes RC, Nussbaum RA, Lynch JD, Green DM, Wheeler WC (2006) The amphibian tree of life. Bulletin of the American Museum of Natural History 297: 1-370.

Katoh K, Standley DM (2013) MAFFT multiple sequence alignment software version 7: improvements in performance and usability. Molecular Biology and Evolution 30: 772-780. doi: 10.1093/molbev/mst010

Köhler J, Böhme W (1996) Anuran amphibians from the region of precambrian rock outcrops (inselbergs) in northeastern Bolivia, with a note on the gender of Scinax Wagler, 1830 (Hylidae). Revue française d'aquariologie herpétologie 23: 133-140.

Liedtke HC, Müller H, Hafner J, Nagel P, Loader SP (2014) Interspecific patterns for egg and clutch sizes of African Bufonidae (Amphibia: Anura). Zoologischer Anzeiger 253: 309-315. doi: 10.1016/j. jcz.2014.02.003

Martin RF (1972) Evidence from osteology. In: Blair WF (Ed.) Evolution in the genus Bufo. University of Texas Press, Austin \& London, 37-70.

McLachlan AJ (1981) Food sources and foraging tactics in tropical rain pools. Zoological Journal of the Linnean Society 71: 265-277. doi: 10.1111/j.1096-3642.1981.tb01133.x

McLachlan AJ, Cantrell MA (1980) Survival strategies in tropical rain pools. Oecologia 47: 344-351. doi: 10.1007/BF00398528

Onadeko AB, Rödel M-O (2009) Anuran surveys in south-western Nigeria. Salamandra 45: 1-14.

Osborne PL, McLachlan AJ (1985) The effect of tadpoles on algal growth in temporary, rain-filled rock pools. Freshwater Biology 15: 77-87. doi: 10.1111/j.1365-2427.1985.tb00697.x
Porembski S, Barthlott W (2000) Inselbergs - Biotic diversity of isolated rock outcrops in tropical and temperate regions. Ecological Studies 146, Springer, Heidelberg.

Rödel M-O (1998) Kaulquappengesellschaften ephemerer Savannengewässer in Westafrika. Edition Chimaira, Frankfurt/M.

Rödel M-O (2000) Herpetofauna of West Africa, Vol. I: Amphibians of the West African savanna. Edition Chimaira, Frankfurt/M.

Rödel M-O, Ernst R (2004) Measuring and monitoring amphibian diversity in tropical forests. I. An evaluation of methods with recommendations for standardization. Ecotropica 10: 1-14.

Rödel M-O, Onadeko AB, Barej MF, Sandberger L (2012) A new polymorphic Phrynobatrachus (Amphibia: Anura: Phrynobatrachidae) from western Nigeria. Zootaxa 3328: 55-65.

Ronquist F, Teslenko M, van der Mark P, Ayres DL, Darling A, Hohna S, Larget B, Liu LL, Suchard MA, Huelsenbeck JP (2012) MrBayes 3.2: Efficient bayesian phylogenetic inference and model choice across a large model space. Systematic Biology 61: 539-542. doi: 10.1093/sysbio/sys029

Schiøtz A (1963) The amphibians of Nigeria. Videnskabelige Meddelelser fra Dansk Naturhistorisk Forening 125: 1-92+ 4 plates.

Schiøtz A, Tandy M (2004) Amietophrynus perreti. IUCN Red List of Threatened Species. Version 2013.2. available at: www.iucnredlist. org. [Last accessed on 1 June 2014]

Schorr G (2003) Die Amphibiengemeinschaften auf Inselbergen im TaïNationalpark, Côte d'Ivoire, Westafrika. Gemeinschaftsökologische und inselbiogeographische Aspekte. Unpublished diploma thesis, Julius-Maximilians-University, Würzburg, 90 pp.

Stuart S, Hoffman M, Chanson J, Cox N, Berridge R, Ramani P, Young B (2008) Threatened amphibians of the World. Lynx Editions, Barcelona.

Swofford DL (2003) PAUP*. Phylogenetic analysis using parsimony (*and other methods). Version 4.0b10. Sinauer Associates, Sunderland, Massachusetts

Tandy M, Keith R (1972) Bufo of Africa. In: Blair WF (Ed.) Evolution in the genus Bufo. University of Texas Press, Austin \& London, 119-170.

\section{Appendix}

\section{Specimens investigated}

Amietophrynus perreti: ZMB 80331 (female, $61.1 \mathrm{~mm}$ SVL), Nigeria, Ondo State, Idanre Hills, $7^{\circ} 6^{\prime} 32.28^{\prime \prime} \mathrm{N}$, 56'45.3"E, 13 March 2014, GenBank\#: KM219928, from a bush along a small stream flowing down the rock, leg. A.B. Onadeko; ZMB 80332 (female, $64.4 \mathrm{~mm}$ ), $7^{\circ} 8^{\prime} 4.2^{\prime \prime} \mathrm{N}, 5^{\circ} 6^{\prime} 2.1^{\prime \prime E}$, all other data as in ZMB 80331; ZMB 80333 (cf. female, $55.3 \mathrm{~mm}$ ), 14 March 2014, 76'44.64"N, 56'34.62"E, GenBank\#: KM219927, all other data as in ZMB 80331; ZMB 80334 (female, 60.5 mm); ZMB 80335 (male $40.2 \mathrm{~mm}$ ); ZMB 80336 (male $39.4 \mathrm{~mm}$ ); ZMB 80337 (male, $36.6 \mathrm{~mm}$ ); 26-28 October 2013, all other data as in ZMB 80331.

Amietophrynus regularis: ZMB 80338 (female, $65.3 \mathrm{~mm}$ ) \& ZMB 80339 (male, $64.6 \mathrm{~mm}$ ), 26-28 October 2013, all other data as in ZMB 80331. 